\section{Szent-Györgyi and vitamin C}

SIR-The book review by Walter Gratzer ${ }^{1}$ describes the isolation of vitamin C in 1932. He says, correctly, that J. L. Svirbely went from C. G. King's laboratories in Pittsburgh to Albert Szent-Györgyi's laboratory in Szeged, where Svirbely tested SzentGyörgyi's hexuronic acid with guinea pigs and found that it was vitamin C. Reflecting the way events are recounted in the book, Gratzer then says that King, upon receiving a letter from Svirbely with this information, "promptly and shamelessly jumped the gun and got a paper off to Science".

This is defamatory to King and is quite incorrect. It is compounded by Gratzer's statement that the book (by Moss) is "clear-eyed, scholarly and scrupulous". The pertinent events were as follows ${ }^{2,3}$ : W. A. Waugh, a student in King's laboratory, obtained crystalline vitamin $\mathrm{C}$ from lemon juice, in September 1931, with constant assay activity in scorbutic guinea pigs. These results were repeated, and Waugh and King submitted an abstract for the 27-30 April 1932 meeting of the American Society of Biological Chemists. As nearly as I can find out, abstracts then had to be submitted before the end of February to be placed on the programme of the meeting. This is in accordance with King's statement that a few weeks after this submission, King received a letter from Svirbely (as noted by Gratzer) in Szent-Györgyi's laboratory, saying that they were "just finishing their first assay in which animals ... . were protected from scurvy when given $1 \mathrm{mg}$ of hexuronic acid daily" and that they were sending a report to Nature (published 16 April 1932) ${ }^{4}$. The report did not mention that Svirbely had spent the previous year working with King and that he and King had co-authored a paper on preparation of vitamin C concentrates from lemon juice ${ }^{5}$. In short, the news was brought from Ghent to Aix, not, as Gratzer claims, from Aix to Ghent! In contrast to the omission of reference to their work by Svirbely and Szent-Györgyi, King and Waugh in Science ${ }^{6}$ stated that recrystallized vitamin $\mathrm{C}$ from lemon juice "is apparently identical with the hexuronic acid described by Szent-Györgyi", thus giving credit to Szent-Györgyi for his role.

Far from "jumping the gun", King actually delayed submission of his manuscript to Science until he had checked the spurious claim of $\mathrm{O}$. Rygh that vitamin $\mathrm{C}$ was methylnornarcotine $\mathrm{e}^{3,7.8}$.

It should be noted that S. S. Zilva had reported erroneously that Szent-Györgyi's hexuronic acid was not Vitamin $C^{3,7.9}$, and that King and Waugh corrected Zilva's mistake ${ }^{3}$

This brings up the question: when is a vitamin identified? The answer is: not until its biological activity is established. Funk, who had predicted the existence of an anti-pellagra 'vitamine' (he coined the word 'vitamine', now 'vitamin'), isolated nicotinic acid from yeast in $1913^{10}$, but it was not tested against canine black tongue or human pellagra until 1937 and so was not recognized as a vitamin until then, without credit going to Funk. SzentGyörgyi isolated hexuronic acid in $1928^{11}$, but it was not tested against scurvy until 1932. The test was carried out by Svirbely, not by Szent-Györgyi ${ }^{12}$.

At my invitation, in 1979, King described the history of the isolation of vitamin $\mathrm{C}$ at the annual meeting of the American Institute of Nutrition ${ }^{3}$. King's scientific conduct in the vitamin $\mathrm{C}$ episode, as on all other occasions, was exemplary and punctilious ${ }^{2}$, and, in my opinion, over-reticent on this issue, despite the fact that he did not share in the Nobel Prizes for vitamin C in 1937. It is unfortunate that this slur has appeared within a short time of King's death on 23 January 1988 .

Thomas H. Jukes

Department of Biophysics and Medical Physics,

University of California, Berkeley, Berkeley, California 94720, USA

1. Gratzer, W. Nature 331, 397-398 (1988).

2. Stare, F. J. \& Stare, I. M. J. Nutr. (in the press).

3. King, C. G. Fedn. Proc. 38, 2681-2683 (1979).

4. Svirbely, J. L. \& Szent-Györgyi, A. Nature 129, 576-577 (1932)

5. Svirbely, J. L. \& King, C. G. J. biol. Chem 94, 483-490 (1931)

6. King, C. G. \& Waugh, W. A. Science 75, 357-358 (1932) . Harris, L. Ann. Rev. Biochem. 2, 253-298 (1933).

Nature 129, 293 (1932)

Zilva, S. S. Nature 129, $690(1932)$

0. Funk, C. J.Physiol, Lond 46, 173-178(1913)

11. Szent-Györgyi. A. Biochem. J. 22, 1387-1393 (1928)

2. Szent-Györgyi, A. Ann. Rev. Biochem 32, 1-14 (1963).

SIR-I would like to correct some misconceptions appearing in Walter Gratzer's otherwise excellent review of Free Radical: Albert Szent-Györgyi and the Battle Over Vitamin C (Nature 331, 397-398; 1988). I had the privilege of collaborating closely with Szent-Györgyi during the last 12 years of his life and enjoyed the friendship of many of those who collaborated with him before and during that time. To state, as the reviewer does, that Szent-Györgyi "often perverted" the talents of his scientific followers is a concept that does not come out of the book and incorrectly reflects the integrity and spirit of the scientific collaborations which occurred.

The reviewer also states that the National Foundation for Cancer Research which supported Szent-Györgyi's work for 13 years "collapsed in squalor and recrimination" and yet the book (p. 257) describes how "for reasons difficult to fathom" the foundation's fund-raising fell but "has since begun to stabilize". I currently receive funding from the foundation and my involvement with the "international, interdisciplinary, laboratory without walls" approach of its support for basic research remains one of my most exciting experiences. It is true that in the last year of his life Szent-Györgyi was in conflict with the foundation's administration, but I believe the previous 12 years of mutual goodwill and support far outweighed this unfortunate situation.

Finally, and here the reviewer does correctly reflect the book, the image is given that "influenced by his young wife, Szent-Györgyi became alienated from his family and friends" and at the end became "lonely, embittered and unfulfilled". During that last summer (and for many before that) my family and I were house guests of the Szent-Györgyis in the summer cottage by their house. Marcia SzentGyörgyi lovingly devoted herself to the care of her husband and encouraged visitors whenever possible (one such visitor was Linus Pauling). Although SzentGyörgyi was seriously ill, he remained interested in and positive about the science in his laboratory, and he retained his impish sense of humour and philosophical view of life. If there is one criticism I would make of the biography of SzentGyörgyi, it would be that the author did not allow himself enough time to obtain a wider and more balanced view of those last few years.

Institute of Molecular and

Ronald Pethic

Biomolecular Electronics,

University of Wales, Bangor, Bangor, Gwynedd LL57 1UT, UK

\section{India and China}

SIR-In my opinion the letter by N. H. Antia, "India since independence" (Nature 331, 384; 1988) contained inaccurate statistics and factual errors.

It is difficult to compare India and China because precise statistics are difficult to obtain from a closed system such as China's. Nevertheless, available data indicate that India leads China in most fields, besides having the third largest technical manpower in the world (after the Soviet Union and the United States)

China lost an entire generation of scientists to the cultural revolution while science in India benefits from free interaction of Indian scientists with those in Western and Eastern bloc countries. The number of contributions to scientific journals coming from Indian as opposed to Chinese laboratories demonstrates this.

Moreover, the sound defeat of the Chinese during the 1979 Sino-Vietnamese conflict indicated the backwardness of the Chinese arms industry, which may reflect the state of her heavy industry as a whole. UPINDER FOTADAR Department of Molecular Pharmacology, Albert Einstein College of Medicine, Bronx, New York 10461, USA 